\title{
Passion fruit (Passiflora edulis) leaf extract modulates the oxidative metabolism of rat peritoneal neutrophils in a model of inflammation
}

\author{
Cleiber Lucan Alves Araújo ${ }^{1}$, Bruno Cesar Correa Salles ${ }^{1}$, \\ Stella Maris da Silveira Duarte ${ }^{1}$, Maria Rita Rodrigues ${ }^{1}$, \\ Fernanda Borges de Araújo Paula ${ }^{\circledR 1^{*}}$
}

${ }^{1}$ Department of Clinical and Toxicological Analysis, Faculty of Pharmaceutical Sciences, Federal University of Alfenas, Alfenas, Minas Gerais, Brazil

\begin{abstract}
This study was conducted to evaluate the effect of extracts of Passiflora edulis Sims leaves on the oxidative metabolism of rat peritoneal neutrophils using a model of acute inflammation. The extract was obtained by maceration in $70 \%$ ethanol, evaporation under reduced pressure and lyophilisation. Total phenolic content (TP) was determined by the Folin-Ciocalteu assay. The P. edulis extract, in different doses, was administered by gavage $1 \mathrm{~h}$ prior to inflammation induction by carrageenan $(8 \mathrm{mg} / \mathrm{kg}$, i.p.); five hours later, the neutrophils were obtained by intraperitoneal lavage. The tests performed in neutrophils were cytochrome $\mathrm{C}$ and chemiluminescence assay as well as myeloperoxidase (MPO), superoxide dismutase (SOD), glutathione peroxidase (GPx) and catalase (CAT) activities. The administration of the extract reduced the number of neutrophils recruited to the site of inflammation; however, the extract did not alter the activity of NADPH oxidase as well as SOD activity in these cells. The MPO and CAT activities in peritoneal neutrophils of rat treated with extract was lower than in the control group, and the GPx activity was increased. Based on the experimental model utilised, the anti-inflammatory potential of $P$. edulis leaf extract could be related to the presence of phenolic compounds in the extract.
\end{abstract}

Keywords: Passiflora edulis Sims. Inflammation. Neutrophil. Reactive oxygen species (ROS). Antioxidant enzymes.

\section{INTRODUCTION}

Neutrophils are recruited at the onset of the pathogen defence response as an essential component of the acute inflammatory process. The killing and microbicidal functions of neutrophils are directly related to activation of the NADPH oxidase system, which generates reactive oxygen species (ROS) in a process called oxidative burst. Molecular oxygen undergoes a one-electron reduction generating

\footnotetext{
*Correspondence: F. Borges de Araujo Paula, Departamento de Análises Clínicas, Faculdade de Ciências Farmacêuticas, Universidade Federal de Alfenas, Rua Gabriel Monteiro da Silva, 700. Centro, 37130-000 - Alfenas - MG, Brazil. Tel.: 55-35-3299-1223. E-mail adresses: fernanda.paula@ unifal-mg.edu.br; fbapaula@yahoo.com.br
}

superoxide anions $(\mathrm{O} 2 \bullet-)$, the precursor to a number of more reactive metabolites, such as hydroxyl radicals or hypochlorous acid $(\mathrm{HOCl})$. These metabolites play essential roles in killing many types of bacteria and other invaders. $\mathrm{HOCl}$ is highly microbicidal and its formation requires myeloperoxidase (MPO), the principal enzyme located in azurophil granules of neutrophils (Bylund et al., 2010; Babior, 2002; Hampton et al., 1998; Klebanoff, 2005).

Despite the regulation of ROS production and use, this oxidative metabolism can set off an ongoing inflammatory process, leading to an oxidative stress status that can cause serious damage to the host organism. In such cases, endogenous antioxidants are often unable to prevent oxidative damage and require exogenous scavengers that 
are obtained from the diet, such as vitamins, minerals, carotenoids and polyphenols (Ciz et al., 2012; Pruchniak et al., 2013; Silva et al., 2014; Zhang, Tsao, 2016).

Passion fruit (Passiflora edulis Sims) is popular for its pulp and the medicinal use of its leaves. The plant has been largely used in American and European countries as a sedative or tranquiliser (Dhawan et al., 2004; Coleta et al., 2006; Petry et al., 2001). Recently, the leaves have been recognised for their anti-inflammatory potential (Montanher et al., 2007). The predominant compounds of Passiflora species are polyphenols, which are known for their antioxidant properties (Ferreres et al., 2007; Zeraik, Yariwake, 2010; Medina et al., 2017).

In the literature, little data exist on the effects of $P$. edulis on the oxidative metabolism of neutrophils in inflammation. Thus, considering that oxidative stress has been linked to the development of several diseases (Carocho, Ferreira, 2013), this study evaluated the effects of P. edulis leaf extract on the oxidative metabolic processes in rat peritoneal neutrophils by assessing ROS production and the activity of antioxidant enzymes of these cells.

\section{MATERIALS AND METHODS}

\section{Plant material}

The leaves of Passiflora edulis Sims (Passifloraceae) were collected in Alfenas, Minas Gerais, Brazil, in September of 2012 and identified by Prof Dr Douglas Carvalho of the Department of Biology at the Universidade Federal de Lavras (UFLA), Lavras, Minas Gerais, Brazil. A voucher specimen was deposited in the Herbarium at the same university (n. 22356).

\section{Extract preparation}

P. edulis leaves were air-dried at $40{ }^{\circ} \mathrm{C}$ for 3 days. The dried and powdered leaves were extracted by maceration using 70\% ethanol (Sinth, Brazil) (plant solvent, 1:10, $\mathrm{w} / \mathrm{v}$ ) for seven days. The extract was then filtered, evaporated under reduced pressure, and lyophilised, yielding a dry residue, according to Salles (2017).

\section{Total phenolic content}

The total phenolic content of the $P$. edulis extract was determined according to the Folin-Ciocalteu method (Singleton et al., 1999). Briefly, crude extracts were dissolved in water for a final concentration of $1 \mathrm{mg} / \mathrm{mL}$ prior to testing. An aliquot of $100 \mu \mathrm{L}$ of the extract solution was mixed with $500 \mu \mathrm{L}$ of Folin-Ciocalteu reagent (Sigma Aldrich, USA). After $8 \mathrm{~min}, 400 \mu \mathrm{L}$ of sodium carbonate solution $4 \%$ was added. The mixture was allowed to stand for $2 \mathrm{~h}$ at room temperature before the absorbance was measured spectrophotometrically at $740 \mathrm{~nm}$. The experiment was conducted in triplicate. Gallic acid (Inlab, Brazil) was used to create a standard curve. The total phenolic content of the sample was expressed as gallic acid equivalents (GAE) to $1.0 \mathrm{~g}$ of extract.

\section{Animals}

In total, 42 adult Wistar male rats, weighing approximately $350 \pm 50 \mathrm{~g}$, were obtained from the Universidade Federal de Alfenas (UNIFAL-MG). Animals were kept at a controlled temperature of 23 $\pm 2{ }^{\circ} \mathrm{C}$ with alternating $12 \mathrm{~h}$ periods of light and dark and were allowed access to food and water ad libitum. All in vivo experiments followed the guidelines of the International Council for Laboratory Animal Science and were approved by the Ethical Committee for Animal Experimentation of UNIFAL-MG (protocol number 523).

\section{Experimental groups}

The $P$. edulis extract, in different doses $(5,50$ and 300 $\mathrm{mg} / \mathrm{kg}$ ), was administered by oral gavage (p.o.) $1 \mathrm{~h}$ prior to inflammation induction, around 7:00 a.m. We employed an experimental model of inflammation in which rat neutrophils are primed in vivo by the intraperitoneal (i.p.) administration of carrageenan (C) (Sigma Aldrich, USA) solubilised in saline. Animals were placed into 6 groups of 7 animals each: (S) animals not treated with carrageenan or extract, but were treated with sterile saline $(10 \mathrm{~mL} / \mathrm{kg}$, i.p.) to obtain peritoneal lavage; (D) animals treated with dexamethasone $(5 \mathrm{mg} / \mathrm{kg}$, p.o.) plus carrageenan $(8 \mathrm{mg} /$ $\mathrm{kg}$, i.p.); (E5) animals treated with extract (5 mg/kg, p.o.) plus carrageenan $(8 \mathrm{mg} / \mathrm{kg}$, i.p.); (E50) animals treated with extract (50 mg/kg, p.o.) plus carrageenan $(8 \mathrm{mg} / \mathrm{kg}$, i.p.); and (E300) animals treated with extract $(300 \mathrm{mg} /$ $\mathrm{kg}$, p.o.) plus carrageenan ( $8 \mathrm{mg} / \mathrm{kg}$, i.p.). The number of animals for each experimental and control groups is indicated in Figure 1. All data are presented as the mean \pm standard deviation (SD) from independent experiments. In each experiment, one animal from each group was analysed. The determinations of the parameters analysed were performed in duplicate or triplicate, as indicated in each item. 


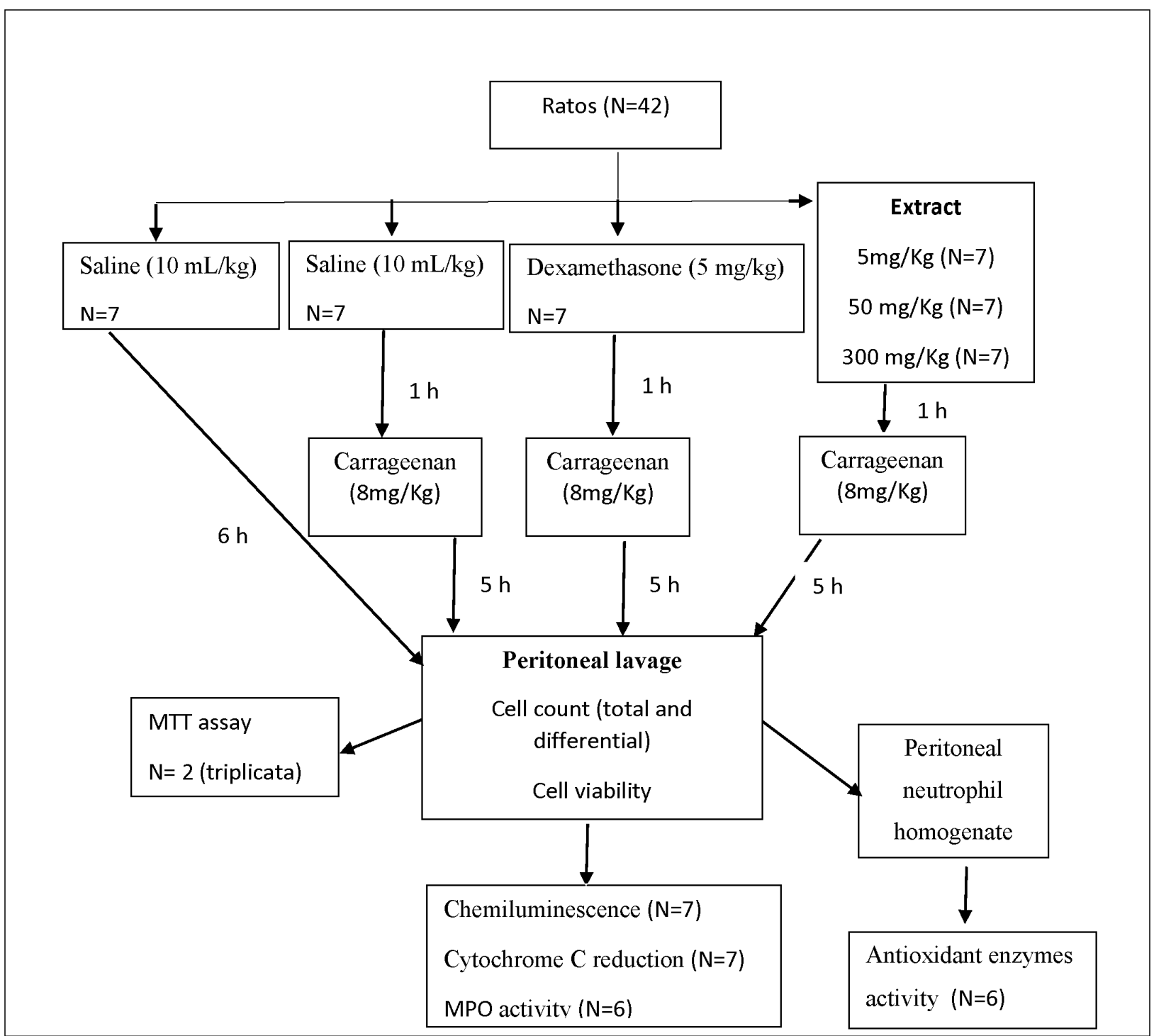

FIGURE 1 - Experimental delineation.

\section{Neutrophil recruitment and cell preparation}

The animals were sacrificed 5 hours after the carrageenan administration. Neutrophils were obtained by intraperitoneal lavage with $15 \mathrm{~mL}$ of phosphate-buffered saline (PBS, pH 7.4). After a gentle massage of the abdomen, the cell suspension was collected by aspiration with a syringe containing a $40 \times 12 \mathrm{~mm}$ needle and was centrifuged at $4{ }^{\circ} \mathrm{C}(1,500 \mathrm{rpm}$ for $5 \mathrm{~min})$. The cell pellet was re-suspended in glucose-PBS (PBS containing 0.5 $\mathrm{mM} \mathrm{MgCl} 2,1 \mathrm{mM} \mathrm{CaCl} 2$ and $1 \mathrm{mg} / \mathrm{mL}$ of glucose). The counting of the peritoneum cells was performed in a Neubauer chamber, using 19 parts of Türk liquid (acetic acid 3\% and methylene blue 1\%) and 1 part of cell suspension (dilution 1/20). For the evaluation of cell morphology, the slides were stained by the MGG method modified by Rosenfeld (1947).The number of viable cells ( $>95 \%$ neutrophils) was determined in a Neubauer chamber (Knittel Glaser, Braunschweig, Germany) under an optical microscope by Trypan blue exclusion.

\section{Cytotoxicity (MTT assay)}

The cytotoxic effect of the extract on rat neutrophils was evaluated by the ability of living cells to reduce the yellow dye 3-(4,5-dimethyl-2-thiazolyl)-2,5-diphenyl2H-tetrazolium bromide (MTT - Sigma Aldrich, USA) to a purple formazan product (Mosmann, 1983). 
Peritoneal neutrophils from the different treatment groups were re-suspended in RPMI-1640 medium and plated in 96 -well plates $(200 \mu \mathrm{L}$ of $1 \times 106$ cells per millilitre in each well) with $20 \mu \mathrm{L}$ of MTT solution (5 $\mathrm{mg} / \mathrm{mL}$ RPMI-1640). The cells were incubated for 2 hours at $37^{\circ} \mathrm{C}$ and $5 \% \mathrm{CO} 2$. The contents of each well were centrifuged $(1200 \mathrm{~g}, 10 \mathrm{~min})$. The supernatant was then discarded and sediment was re-suspended adding $100 \mu \mathrm{L} /$ well of isopropyl alcohol for dissolving the MTT formazan product. The optical density was read at $540 \mathrm{~nm}$ with a reference filter at $620 \mathrm{~nm}$ using a microplate reader. A second plate was prepared under the same conditions and incubated for 18 hours. All data are presented as the mean \pm standard deviation (SD) from two independent experiments conducted in triplicate.

\section{NADPH oxidase system activity (cytochrome C reduction)}

The production of superoxide anions $(\mathrm{O} 2 \bullet-)$ by NADPH oxidase in neutrophils was monitored by the reduction of cytochrome $\mathrm{C}$. The test was conducted in a plastic bucket containing $2 \times 106$ neutrophils per millilitre, $100 \mu \mathrm{M}$ cytochrome C (Sigma Aldrich, USA) and $20 \mu \mathrm{g} / \mathrm{mL}(958 \mathrm{U} / \mathrm{mL}$ ) catalase (Sigma Aldrich, USA) in glucose-PBS. The buckets were kept at $37^{\circ} \mathrm{C}$ for 5 minutes. Superoxide production was initiated by the addition of PMA (Forbol 12-miristate 13-acetate, Sigma Aldrich, USA) $(100 \mathrm{ng} / \mathrm{mL})$. After the addition of PMA, the reaction was monitored by spectrophotometry for 3 min at a wavelength of $550 \mathrm{~nm}$ (Jones, Hancock, 1994).

\section{Luminol-amplified chemiluminescence}

The chemiluminescence of luminol is commonly used to evaluate the oxidative burst that occurs when intact phagocytes are activated by the addition of a stimulus such as PMA in an assay termed luminolamplified chemiluminescence of activated phagocytes. For this assay, neutrophils were activated with PMA (53 ng per test) in a reaction mixture containing $1 \mathrm{mM}$ of luminol (Sigma Aldrich, USA) and 1 x 106 neutrophils per millilitre. The chemiluminescent intensities of $0.3 \mathrm{~mL}$ samples were followed in a Geomax luminometer ${ }^{\circledR}$ 20/20. The chemiluminescence is expressed as relative light units per second (RLU/s). The reaction was performed in PBS, pH 7.4, and followed for $30 \mathrm{~min}$. All measurements were made at $37^{\circ} \mathrm{C}$ (Souza Ferreira et al., 2012).

\section{Myeloperoxidase activity (HOCl formation)}

Peritoneal neutrophils ( $3 \times 106$ cells per millilitre) were incubated with $12 \mathrm{mM}$ taurine (Sigma Aldrich, USA) in glucose-PBS at $37{ }^{\circ} \mathrm{C}$ and were stimulated with PMA $100 \mathrm{ng} / \mathrm{mL}$. After $30 \mathrm{~min}$, the reactions were stopped by adding $20 \mu \mathrm{g} / \mathrm{mL}(958 \mathrm{U} / \mathrm{mL})$ catalase (Sigma Aldrich, USA) and placing the tubes in melting ice for $5 \mathrm{~min}$. Cells were pelleted by centrifugation at $4{ }^{\circ} \mathrm{C}(12000 \mathrm{rpm}$ for $10 \mathrm{~min})$. The concentration of accumulated taurine chloramine present in the supernatants was quantified by measuring the oxidation of 5-thio-2-nitrobenzoic acid (TNB) to 5,5'-dithiobis-(2nitrobenzoic acid) (DTNB) by the associated decrease in absorbance at $412 \mathrm{~nm}$, as previously described (Kettle, Winterbourn, 1994).

\section{Antioxidant enzymes activity}

\section{Peritoneal neutrophil homogenate}

Peritoneal neutrophils were disrupted with sonication at $30 \mathrm{kHz}$ output for two cycles of 30 seconds with 15 seconds rest intervals on melted ice. Unbroken cells were pelleted by centrifugation at $4{ }^{\circ} \mathrm{C}(3000 \mathrm{rpm}$ for $5 \mathrm{~min}$ ) and the supernatant was used to determine the protein content and the activity of antioxidant enzymes.

\section{Protein determination}

The protein content of the peritoneal neutrophils homogenate was measured using the Bradford method (Bradford, 1976), using BSA (Sigma Aldrich, USA) as the standard. An aliquot corresponding to $35 \mu \mathrm{g}$ of protein of this homogenate was used to determine the activity of antioxidant enzymes.

\section{Superoxide dismutase (SOD) activity}

SOD activity was assayed by the method of Oyanagui (Oyanagui, 1984). Aliquots of the peritoneal neutrophil homogenate were incubated with $3 \mathrm{mM}$ hydroxylamine (Sinth, Brazil), $0.07 \mathrm{mM}$ hypoxanthine (Sigma Aldrich, USA) and $3.4 \times 10-3 \mathrm{U} / \mathrm{mL}$ xanthine oxidase (Sigma Aldrich, USA) at $37^{\circ} \mathrm{C}$ for 30 minutes in the dark. After incubation, a solution of sulfanilic acid (Sinth, Brazil), naphthalene diamine (Sigma Aldrich, USA) and glacial acetic acid (Acros organics, USA) was added and kept at room temperature for 20 minutes. The absorbance was 
determined at $550 \mathrm{~nm}$. SOD activity was expressed in units per milligram of protein (U/mg protein). One SOD unit (U) was defined as the enzyme activity that inhibits $50 \%$ of the reaction in this condition.

\section{Catalase (CAT) activity}

CAT activity was estimated as described by Aebi (1984). Aliquots of the peritoneal neutrophil homogenate were incubated in PBS ( $\mathrm{pH} 7.4$ ) and the reduction of 10 mM H2O2 (Sinth, Brazil) was monitored by measuring the absorbance at $240 \mathrm{~nm}$ for 1 minute. The activity was calculated by using a molar absorption coefficient and the enzyme activity was expressed in $\mathrm{U} / \mathrm{mg}$ protein. One CAT U was defined as the enzyme activity that decomposes $1 \mu \mathrm{mol}$ of $\mathrm{H} 2 \mathrm{O} 2$ per minute.

\section{Glutathione peroxidase (GPx) activity}

GPx was measured using the method described by Sinet and co-workers (Sinet et al., 1975) employing t-butyl hydroperoxide (Sigma Aldrich, USA) as the substrate. Aliquots of the peritoneal neutrophil homogenate were incubated in PBS ( $\mathrm{pH}$ 7.4) with $1 \mathrm{mM}$ reduced glutathione (Sigma Aldrich, USA), $0.2 \mathrm{mM}$ NADPH (Sigma Aldrich, USA) and $1.8 \mathrm{U} /$ $\mathrm{mL}$ glutathione reductase (Sigma Aldrich, USA) for 3 minutes at $37^{\circ} \mathrm{C}$. The absorbance was monitored at $340 \mathrm{~nm}$. After 3 minutes of incubation, the reaction was initiated by the addition of $0.9 \mathrm{mM} t$-butyl hydroperoxide. The absorbance was monitored for five more minutes at $340 \mathrm{~nm}$. GPx activity was expressed in U/mg protein. One GPx U was defined as the enzyme activity that consumes $1 \mu \mathrm{mol}$ of $\mathrm{NADPH} / \mathrm{min}$.

\section{Statistical analysis}

The results were expressed as the mean \pm standard deviation; they were also submitted to one-way analysis of variance and compared using the Scott-Knott test at $5 \%$ significance.

\section{RESULTS}

\section{Yield and total phenolic content}

Overall, $18.6 \mathrm{~g}$ of extract of Passiflora edulis Sims leaves was obtained for each $100 \mathrm{~g}$ of dry and pulverised vegetable matter.
We used gallic acid to create a standard curve (y $=101.68 \mathrm{x}+0.0249, \mathrm{R} 2=0.9994)$ and the total phenolic content in $P$. edulis extract was determined to be equivalent to $46.7 \pm 1.15 \mathrm{mg}$ GAE g-1.

\section{Neutrophil recruitment and viability}

Animals were treated with $P$. edulis extract $1 \mathrm{~h}$ before carrageenan was used to induce inflammation. The administration of carrageenan to rats induced a significant amount of neutrophil migration compared with the $\mathrm{S}$ group treated intraperitoneally with saline. Animals treated with $P$. edulis extract showed significantly decreased neutrophil migration at all tested doses (Figure 2). As expected, animals that were treated with dexamethasone, which was used as a positive control at a dose of $5 \mathrm{mg} / \mathrm{kg}$, showed a strong inhibition of neutrophil migration.

Figure 3 shows results from the cell viability assay measuring the effect of $P$. edulis extract on peritoneal neutrophils from each of the different treatment groups. Viable neutrophils were quantified by the MTT assay, an established method for probing cell death. There were no significant differences in the peritoneal neutrophil viability between the groups for 2 or 18 hours. These data indicate that the tested doses of $P$. edulis extract $(5,50$ and $300 \mathrm{mg} / \mathrm{kg}$ ) are all nontoxic over at least an 18-h period and can be used safely for further biological studies.

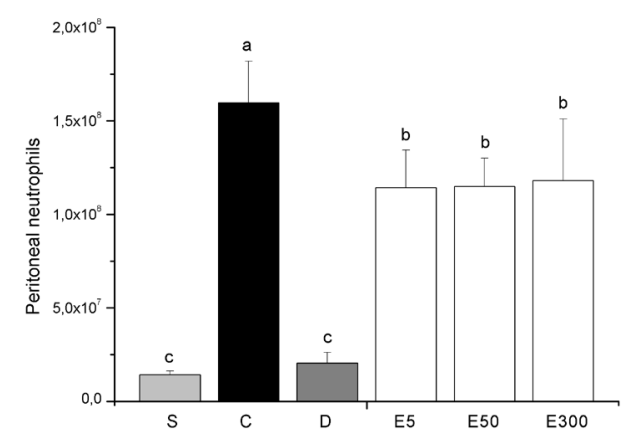

FIGURE 2 - Effect of the treatments on rats' peritoneal neutrophils migration. Results are presented as means $\pm \mathrm{SD}$ of seven animals per group. $\mathrm{S}=$ saline group; $\mathrm{C}=$ carrageenan group; $\mathrm{D}=$ dexamethasone group; E5, E50 and E300 = extracts groups. Different letters indicate statistical significance $(\mathrm{p}<0.05)$. 


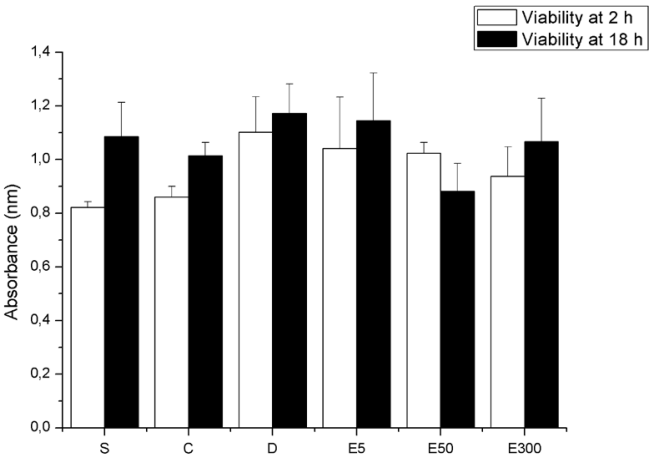

FIGURE 3 - Effect of the treatments on cell viability of rats' peritoneal neutrophils. Cells were incubated for 2 and $18 \mathrm{~h}$, and the viability was measured with MTT assay. Results are presented as means $\pm \mathrm{SD}$ from two experiments performed in triplicate. $\mathrm{S}=$ saline group; $\mathrm{C}=$ carrageenan group; $\mathrm{D}=$ dexamethasone group; E5, E50 and E300 = extracts groups.

\section{NADPH oxidase activity and ROS production}

Cytochrome $\mathrm{C}$ reduction and a chemiluminescence assay were used to assess the generation of $\mathrm{O} 2 \cdot-$ and $\mathrm{ROS}$ by the NADPH oxidase system. Carrageenan increased both $\mathrm{O} 2 \cdot-$ and ROS in peritoneal neutrophils compared with the $\mathrm{S}$ group (Figures $4 \mathrm{~A}$ and $4 \mathrm{~B}$ ). The $\mathrm{O} 2 \bullet-$ production by peritoneal neutrophils treated with $P$. edulis extract did not differ from that by the $\mathrm{C}$ group (Figure 4A). The chemiluminescence assay measured both ROS formation and $\mathrm{O} 2 \cdot-$ generation (Figure 4B), showing that treatment with $P$. edulis extract decreases the amount of ROS produced by peritoneal neutrophils when compared with the $\mathrm{C}$ group. The most significant decrease was observed in the E300 group, which had approximately 69\% lower levels of ROS than observed in the $\mathrm{C}$ group.

\section{MPO activity}

A TNB oxidation assay was used to indirectly measure $\mathrm{HOCl}$ concentration. The peritoneal neutrophils from the $\mathrm{C}$ group showed a increase in $\mathrm{HOCl}$ generation compared with the $\mathrm{S}$ group. The pre-treatment with $P$. edulis extract decreased $\mathrm{HOCl}$ generation compared with the $\mathrm{C}$ group (Figure 5) in a dose-dependent manner (reduction of approximately $22 \%$ in the E5 group, $43 \%$ in the E50 group and 56\% in the E300 group).

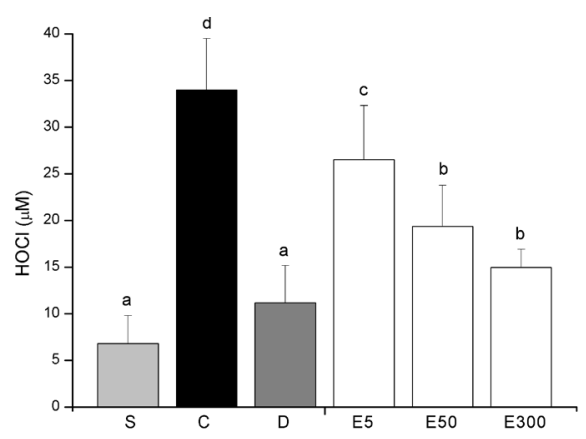

FIGURE 5 - Effect of the treatments on $\mathrm{HOCl}$ production from rats' peritoneal neutrophils. Results are presented as means $\pm \mathrm{SD}$ of six animals per group. $\mathrm{S}=$ saline group; $\mathrm{C}=$ carrageenan group; D = dexamethasone group; E5, E50 and $\mathrm{E} 300=$ extracts groups. Different letters indicate statistical significance $(\mathrm{p}<0.05)$.
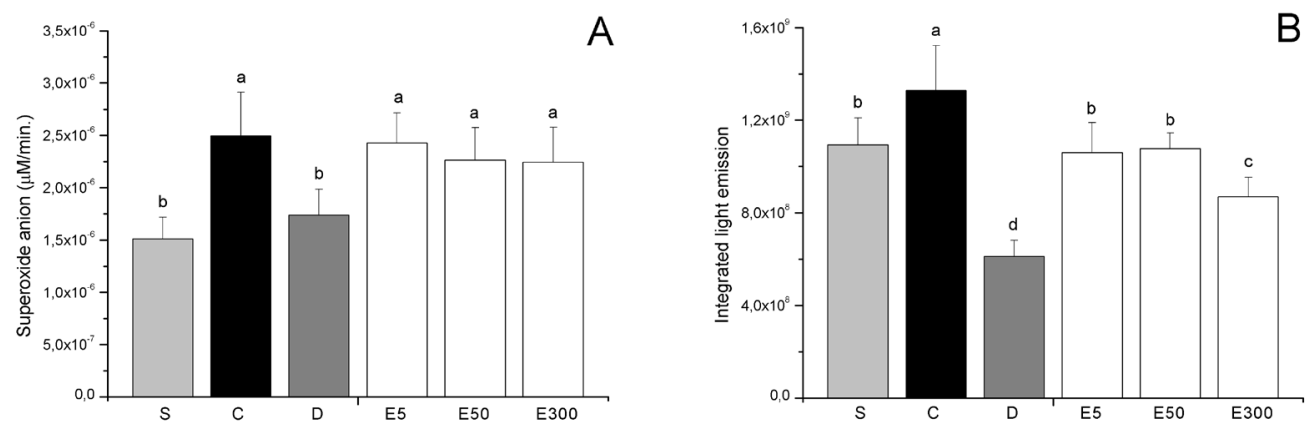

FIGURE 4 - A. Effect of the treatments on $\mathrm{O}_{2} \bullet$ - production by rats peritoneal neutrophils. Results are presented as means $\pm \mathrm{SD}$ of seven determinations of the reduction of cytochrome $\mathrm{C} 100 \mu \mathrm{M}$ by rats peritoneal neutrophils $\left(2 \mathrm{x} 10^{6}\right.$ cells per millilitre) stimulated with PMA $(100 \mathrm{ng} / \mathrm{mL})$. B. Effects of the treatments on ROS production. Results are presented as means \pm SD of the integrated area of light emission obtained for the oxidation of luminol $1 \mathrm{mM}$ promoted by rats peritoneal neutrophils $\left(1 \mathrm{x} 10^{6}\right.$ cells per millilitre $)$ stimulated with PMA $(53 \mathrm{ng} / \mathrm{mL})$ from seven experiments of each group. $\mathrm{S}=$ saline group; $\mathrm{C}=$ carrageenan group; D = dexamethasone group; E5, E50 and E300 = extracts groups. Different letters indicate statistical significance $(\mathrm{p}<0.05)$. 


\section{Activity of antioxidant enzymes}

The increased level of oxidative stress is related to an overproduction of ROS or a deficiency in the antioxidant defence system. The treatment with $P$. edulis extract decreases the ROS production. With regard to effects on antioxidant enzymes, no significant differences in the SOD activity were observed in peritoneal neutrophils from groups treated with the $P$. edulis extract compared to the $\mathrm{C}$ group (Figure 6A). These results are consistent with those obtained regarding the $\mathrm{O} 2 \cdot-$ production (Figure 4A). However, the CAT activity in peritoneal neutrophils from the E300 group was approximately $55 \%$ lower than that in the control group (Figure 6B), and the GPx activity was increased in a dose-dependent manner (Figure 6C), achieving results similar to those in the $\mathrm{S}$ and $\mathrm{D}$ groups.

\section{DISCUSSION}

This study evaluated the anti-inflammatory potential of $P$. edulis leaf extract by employing a model of acute peritonitis, which was induced by the administration of carrageenan. We observed that $P$. edulis extract reduced the number of cells recruited to the site of inflammation and modulated the oxidative metabolism of rat peritoneal neutrophils by decreasing the ROS production and modulating the activity of antioxidant enzymes.

$P$. edulis is rich in phenolic compounds, especially flavonoids C-glycosides derivatives of apigenin and luteolin, such as vitexin, isovitexin, orientin and isoorientin (Dhawan et al., 2004; Ferreres et al., 2007). Salles (2017) confirmed the presence of flavonoid isoorietin and suggested the presence of several flavonoids with an $\mathrm{OH}$ group at C-3', 4', 5 and 7 in the $P$. edulis leaf extract.

Many studies over the past years have shown that polyphenols found in dietary and medicinal plants often possess antioxidant activity that inhibits oxidative damage and may consequently prevent inflammation (Khanna et al. 2007; Manach et al., 2004; Rudnicki et al., 2007). Our results highlight the fact that the P. edulis leaf extract represents a source of phenolic compounds and high antioxidant potential.

Neutrophils are important for host defence; by releasing a series of mediators, neutrophils can induce the accumulation of inflammatory cells (Weiss, 1989). These phagocytic cells play a key role in the front-line
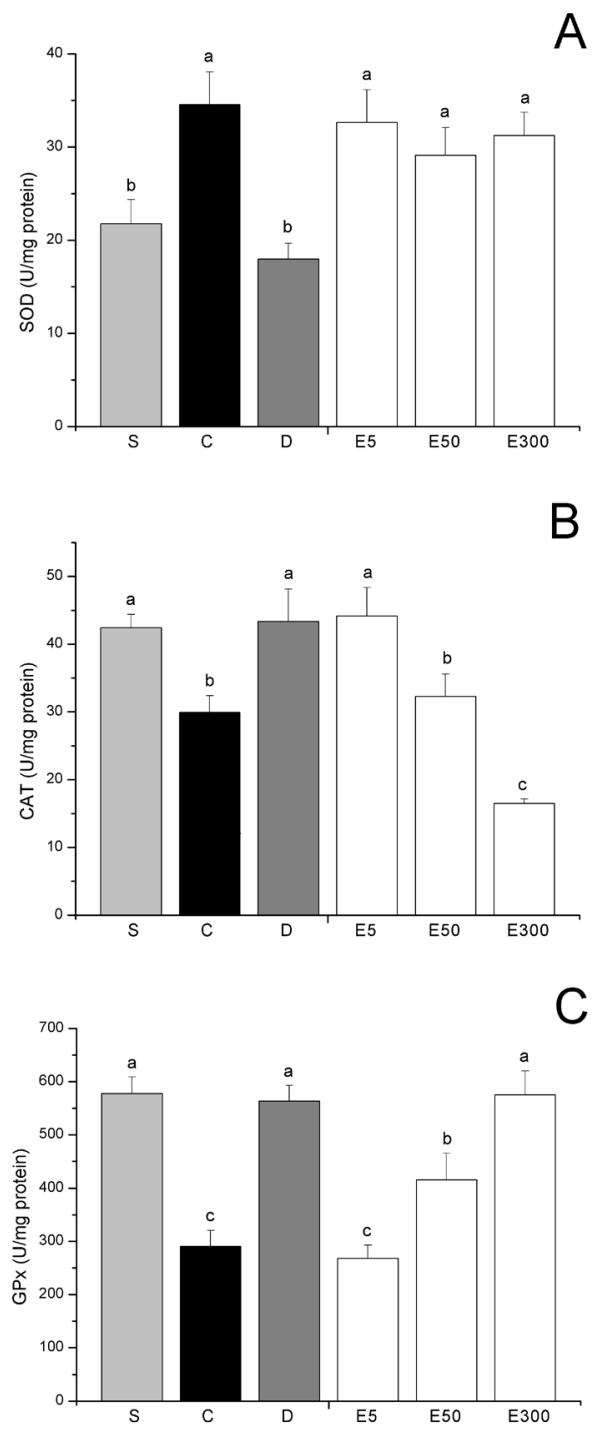

FIGURE 6 - Effect of the treatments on the activity of antioxidant enzymes in rats' peritoneal neutrophils. A. Superoxide anion (SOD). B. Catalase (CAT). C. Glutathione peroxidase (GPx). Results are presented as means $\pm \mathrm{SD}$ of six animals per group. $\mathrm{S}=$ saline group; $\mathrm{C}=$ carrageenan group; $\mathrm{D}$ $=$ dexamethasone group; E5, E50 and E300 = extracts groups. Different letters indicate statistical significance $(\mathrm{p}<0.05)$.

defence, as they are recruited almost immediately to the site of injury or infection (Pruchniak et al., 2013). In our study, 5 hours after the administration of carrageenan $(8 \mathrm{mg} / \mathrm{kg}$, i.p.) in rats, peritoneal neutrophils were collected. The inflammatory effect induced by carrageenan has been linked to neutrophil infiltration and the production of neutrophil-derived ROS (Chang et al., 2012). The data obtained in this study showed that treatment with $P$. edulis leaf extract reduces the level of 
neutrophil migration to the site of inflammation (Figure 2). Moreover, the extract did not show a cytotoxic effect on the cells according to the MTT assay (Figure 3).

Upon activation, neutrophils generate ROS through the NADPH oxidase system in a process known as respiratory burst. The ROS generated by neutrophil activation are able to oxidise molecules such as luminol to excited and unstable intermediates, which can be measured by chemiluminescence (Gasbarrini et al., 1998). In this study, O2•- production was evaluated using a cytochrome $\mathrm{C}$ reduction assay (Figure 4A), and the ROS pool was monitored using chemiluminescence (Figure 4B). Injection of carrageenan into the peritoneal cavity of rats elicited an acute inflammatory response characterised by the accumulation of neutrophils in the peritoneal cavity and increased production of $\mathrm{O} 2 \bullet$, $\mathrm{ROS}$ and $\mathrm{HOCl}$ (Figures 4A, 4B and 5). The NADPH oxidase system activity, reflected by the $\mathrm{O} 2 \cdot-$ production, was similar in the groups treated with $P$. edulis extract and the $\mathrm{C}$ group. However, the ROS pool was decreased in the extract-treated groups when compared to the $\mathrm{C}$ group, especially at the dose of $300 \mathrm{mg} / \mathrm{kg}$. These data show that treatment with the extract did not change the NADPH oxidase activity, yet it interfered with the generation of by-products that result from the activation of this complex or other pathways involved in ROS generation.

The $\mathrm{O} 2 \cdot-$ is a primary product of NADPH oxidase activation, it is required for the generation of more potent molecules, including one of the most potent microbicidal molecules, $\mathrm{HOCl}$. $\mathrm{HOCl}$ is produced by the MPO enzyme in a reaction involving $\mathrm{H} 2 \mathrm{O} 2$ and a chloride ion (Hampton et al., 1998; Dahlgren, Karlsson, 1999; Winterbourn et al., 2000; Biswas, 2016). MPO activity, which is abundant in neutrophil azurophilic granules, was shown to decrease in a dose-dependent manner upon treatment with $P$. edulis extract, as shown by the $\mathrm{HOCl}$ generation in treated groups compared with the $\mathrm{C}$ group (Figure 5).

MPO-deficient neutrophils are classified as "low responders" when ROS are measured by luminolamplified chemiluminescence (Bylund et al., 2010). As $\mathrm{HOCl}$ participates in luminol oxidation, which can be detected by chemiluminescence, the decreased ROS produced by peritoneal neutrophils (Figure 4B) can be explained by the decreased $\mathrm{HOCl}$ observed in extracttreated groups.

Polyphenols have powerful antioxidant activities, mediated by their ability to scavenge a wide range of ROS. Therefore, the effects of various polyphenols on the respiratory burst of phagocytes can be at least partially explained by their antioxidant properties, which diminish adverse oxidative stress by scavenging ROS that have already been produced, including hypochlorous acid (Ciz et al., 2012; Zhang, Tsao, 2016). Thus, the results observed in this study could be attributed to the presence of phenolic compounds in the extract.

Zeraik and co-workers (2011) have demonstrated strong inhibitory effects of $P$. edulis rind extract on MPO, an effect that correlated with the extract's isoorientin content. The results indicated that this compound is able to interact directly at the active site or by otherwise altering the structure of MPO. Thus, the observed dose-dependent decrease in $\mathrm{HOCl}$ production in response to $P$. edulis extract is likely related to the extract's polyphenolic substances. These could act both on the enzyme and HOCl (Zeraik et al. 2011; Zhang, Tsao, 2016).

In most cases, the generation and elimination of ROS function in a dynamic balance. However, the disruption of this balance can lead to a state of oxidative stress, which can damage the body's own cells and tissues. The increased oxidative stress is related to a hyperproduction of ROS or a deficiency in the antioxidant defence system, which consists of enzymatic (SOD, CAT and GPx) and non-enzymatic scavenger components (Ciz et al., 2012).

Our results do not show any difference between the SOD activity in peritoneal neutrophils from the P. edulis extract-treated groups compared with that in the C group (Figure 6A). SOD acts as a first line of defence against $\mathrm{O} 2 \cdot-$ by catalysing the dismutation of this species to $\mathrm{H} 2 \mathrm{O} 2$. Therefore, the SOD activity results are consistent with the results obtained with the cytochrome $\mathrm{C}$ reduction assay (Figure $3 \mathrm{~A}$ ), which showed that the $\mathrm{O} 2 \cdot-$ production in extract-treated groups did not differ from that in the $\mathrm{C}$ group.

Generated $\mathrm{H} 2 \mathrm{O} 2$ is detoxified by conversion into molecular oxygen and water by CAT or GPx (Lei et al., 2014). Our results show that treatment with $P$. edulis extract decreases the CAT activity in peritoneal neutrophils (Figure 6B), while the extract increases the GPx activity of these cells (Figure 6C) in a dosedependent manner.

A previous study showed that flavonoids can inhibit the CAT enzyme (Zhu et al., 2007; Krych, Gebicka, 2013). This inhibitory effect is, at least partially, due to the formation of hydrogen bonds between CAT and flavonoids, which causes conformational changes in the enzyme that inhibit the reaction of $\mathrm{H} 2 \mathrm{O} 2$ with the 
haem centre of the enzyme. The decreased CAT activity should result in an accumulation of $\mathrm{H} 2 \mathrm{O} 2$ in neutrophils, promoting the formation of the highly reactive and damaging hydroxyl radical, which can be formed by the reaction of $\mathrm{H} 2 \mathrm{O} 2$ with $\mathrm{Fe} 2+$ (via the Fenton reaction). A compensatory mechanism for the decreased CAT activity may include increased GPx activity, which is considered one of the most effective enzymes in reducing oxidative stress by the conversion of glutathione into oxidized glutathione (Lubos et al., 2011).

MPO enzyme activity also functions in the elimination of excess $\mathrm{H} 2 \mathrm{O} 2$. Thus, the antioxidant enzymes results associated with reduced $\mathrm{HOCl}$ production leads to two hypotheses about the effects of $P$. edulis extract on the oxidative metabolism of peritoneal neutrophils. The first is that the inhibition of CAT by the extract's phenolic compounds increases the levels of $\mathrm{H} 2 \mathrm{O} 2$, leading to an adaptive response that includes an increase in GPx activity. This regulatory response may sufficiently reduce MPO substrate levels, thereby decreasing $\mathrm{HOCl}$ production. The second hypothesis is that the extract inhibits CAT and MPO activities, resulting in increased $\mathrm{H} 2 \mathrm{O} 2$ levels and a consequential modulation of GPx enzyme activity. Further studies are necessary to thoroughly assess these hypotheses.

\section{CONCLUSIONS}

We demonstrated that $P$. edulis leaf extract is a potential source of strong antioxidant molecules and that it anti-inflammatory and antioxidant potential. According to the results, the extract may modulate oxidative stress and diminish the intensity and endurance of the inflammatory process.

\section{ACKNOWLEDGMENTS}

This study was financed in part by the Coordenação de Aperfeiçoamento de Pessoal de Nivel Superior Brasil (CAPES) - Finance Code 001. The authors thank CAPES and Conselho Nacional de Desenvolvimento Científico e Tecnológico (CNPq, Brazil) by scholarship.

\section{REFERENCES}

Aebi H. Catalase in vitro. Methods Enzymol. 1984;105:121-26.

Babior BM. The leukocyte NADPH oxidase. Isr Med Assoc J. 2002;4(11):1023-1024.
Biswas KS. Does the interdependence between oxidative stress and inflammation explain the antioxidant paradox? Oxid Med Cell Longev. 2016;1-9. Disponível em http://dx.doi. org/10.1155/2016/5698931

Bradford MM. A rapid and sensitive method for the quantitation of microgram quantities of protein utilizing the principle of protein-dye binding. Anal Biochem. 1976;72:248-54.

Bylund J, Brown KL, Movitz C, Dahlgren C, Karlsso NA. Intracellular generation of superoxide by the phagocyte NADPH oxidase: How, where, and what for? Free Radical Biol Med. 2010;49(12):1834-45.

Carocho M, Ferreira IC. A review on antioxidants, prooxidants and related controversy: Natural and synthetic compounds, screening and analysis methodologies and future perspectives. Food Chem Toxicol. 2013;51:15-25.

Chang TN, Deng JS, Chang YC, Lee CY, Jung-Chun L, Lee MM et al. Ameliorative effects of scopoletin from Crossostephium chinensis against inflammation pain and its mechanisms in mice. Evid Based Complementary Altern Med. 2012;2012:1-10.

Ciz M, Denev P, Kratchanova M, Vasicek O, Ambrozova G, Lojek A. Flavonoids inhibit the respiratory burst of neutrophils in mammals. Oxid Med Cell Longev. 2012;2012:1-6.

Coleta M, Batista MT, Campos MG, Carvalho R, Cotrim MD, Lima TC et al. Neuropharmacological evaluation of the putative anxiolytic effects of Passiflora edulis Sims, its subfractions and flavonoid constituents. Phytother Res. 2006; 20(2):1067-73.

Dahlgren C, Karlsson A. Respiratory burst in human neutrophils. J Immunol Methods. 1999;232(1-2):3-14.

Dhawan K, Dhawan S, Sharma A. Passiflora: a review update. J Ethnopharmacol. 2004;94(1):1-23.

Ferreres F, Sousa C, Valentão P, Andrade PB, Seabra RM, GilIzquierdo $\mathrm{A}$. New $C$-deoxyhexosyl flavones and antioxidant properties of Passiflora edulis leaf extract. J Agric Food Chem. 2007;55(25),10187-93.

Gasbarrini A, Pasini P, Nardo B, De Notariis S, Simoncini $\mathrm{M}$, Cavallari A et al. Chemiluminescent real time imaging of post-ischemic oxygen free radicals formation in livers isolated from young and old rats. Free Radic Biol Med. 1998;24(2):211-16.

Hampton MB, Kettle AJ, Winterbourn CC. Inside the neutrophil phagosome: Oxidants, myeloperoxidase and bacterial killing. Blood. 1998;92(9):3007-17. 
Jones OT, Hancock T. Assays of plasma membrane NADPH oxidase. Methods Enzymol. 1994;233:222-29.

Kettle AJ, Winterbourn C.C. Assays for the chlorination activity of myeloperoxidase. Methods Enzymol. 1994;233:502-512.

Khanna D, Sethi G, Ahn KS, Pandey MK, Kunnumakkara AB, Sung B et al. Natural products as a gold mine for arthritis treatment. Curr Opin Pharmacol. 2007;7(3):344-51.

Klebanoff SJ. Myeloperoxidase: friend and foe. J Leukoc Biol. 2005;77(5):598-625.

Krych J, Gebicka L. Catalase is inhibited by flavonoids. Int J Biol Macromol. 2013;58:148-153.

Lei Y, Ren X, Chen J, Liu D, Ruan J. Protective effects of grape seed-derived procyanidin extract against carrageenaninduced abacterial prostatitis in rats. J Funct Foods. 2014;7:416-424.

Lubos E, Loscalzo J, Handy, DE. Glutathione peroxidase-1 in health and disease: from molecular mechanisms to therapeutic opportunities. Antioxid Redox Signal. 2011;15(7):1957-97.

Manach C, Scalbert A, Morand C, Rémésy C, Jiménez L. Polyphenols: food sources and bioavailability. Am J Clin Nutr. 2004;79(5):727-47.

Medina S, Collado-González J, Ferreres F, LondoñoLondoño J, Jiménez-Cartagena C, Guy A. Quantification of phytoprostanes - bioactive oxylipins - and phenolic compounds of Passiflora edulis Sims shell using UHPLCQqQ-MS/MS and LC-IT-DAD-MS/MS. Food Chem. 2017;229:1-8.

Montanher AB, Zucolotto SM, Schenkel EP, Fröde TS. Evidence of anti-inflammatory effects of Passiflora edulis in an inflammation model. J Ethnopharmacol. 2007;109(2):281-88.

Mosmann T. Rapid colorimetric assay for cellular growth and survival: application to proliferation and cytotoxicity assays. J Immunol Methods. 1983;65(1-2):55-63.

Oyanagui Y. Reevaluation of assay methods and establishment of kit for superoxide dismutase activity. Anal Biochem. 1984;142(2):290-296.

Petry RD, ReginattoF, De-Paris F, Gosmann G, Salgueiro JB, Quevedo J et al. Comparative pharmacological study of hydroethanol extracts of Passiflora alata and Passiflora edulis leaves. Phytother Res. 2001;15(2):162-164.
Pruchniak MP, Arazna M, Demkow U. Life of neutrophil: From stem cell to neutrophil extracellular trap. Respir Physiol Neurobiol. 2013;187(1):68-73.

Rosenfeld G. Corante pancrômico para hematologia e citologia clínica: nova combinação dos componentes do MayGrunwald e do Giemsa num só corante de emprego rápido. Mem Inst Butantan. 1947:20:329-334.

Rudnicki M, Oliveira MR, Pereira TV, Reginatto FH, DalPizzol F, Moreira JCF. Antioxidant and anti-glycation properties of Passiflora alata and Passiflora edulis extracts. Food Chem. 2007;100(2):719-724.

Salles BCC. Avaliação dos efeitos do extrato e da fração flavonoídica obtidos das folhas do maracujá (Passiflora edulis Sims) sobre a modulação da NADPH oxidase e agregação plaquetária em ratos diabéticos. [Thesis]. Alfenas: Faculdade de Ciências Farmacêuticas, UNIFAL-MG; 2017.

Silva JK, Cazarin CBB, Batista AG, Maróstica-Jr M. Effects of passion fruit (Passiflora edulis) by-product intake in antioxidant status of Wistar rats tissues. Food Sci Technol. 2014;59(2):1213-19.

Sinet PM, Michelson AM, Bazin A, Lejeune J, Jerome H. Increase in glutathione peroxidase activity in erythrocytes from trisomy 21 subjects. Biochem Biophys Res Commun. 1975;67(3):910-15.

Singleton VL, Orthofer R, Lamuela-Raventós RM. Analysis of total phenols and other oxidation substrates by means of Folin-Ciocalteu reagent. Methods Enzymol. 1999;299:152-78.

Souza Ferreira C, Araújo, TH, Ângelo ML, Pennacchi PC, Okada SS, Paula, FBA et al. Neutrophil dysfunction induced by hyperglycemia: modulation of myeloperoxidase activity. Cell Biochem Funct. 2012;30(7):604-10.

Weiss SJ. Tissue destruction by neutrophils. N Engl J Med. 1989;320(6):365-76.

Winterbourn CC, Vissers MC, Kettle AJ. Myeloperoxidase. Curr. Opin. Hematol. 2000;7(1):53-8.

Zeraik ML, Serteyn D, Deby-Dupont G. Wauters JN, Tits M, Yariwake JH et al. Evaluation of the antioxidant activity of passion fruit (Passiflora edulis and Passiflora alata) extracts on stimulated neutrophils and myeloperoxidase activity assays. Food Chem.2011;128(2):259-65.

Zeraik ML, Yariwake JH. Quantification of isoorientin and total flavonoids in Passiflora edulis fruit pulp by HPLC-UV/ DAD. Microchem J. 2010;96(1):86-91. 
Anti-inflammatory potential of Passiflora edulis leaves

Zhang H, Tsao R. Dietary polyphenols, oxidative stress and antioxidant and anti-inflammatory effects. Curr Opin Food Sci. 2016;8:33-42.
Zhu J, Zhang X, Li D, Jin J. Probing the binding of flavonoids to catalase by molecular spectroscopy. J Mol Struct. 2007;843(1):38-44.

Received for publication on $17^{\text {th }}$ June 2017 Accepted for publication on $20^{\text {th }}$ May 2019 